\title{
Assistive technology and passengers with special assistance needs in air transport: contributions to cabin design
}

\author{
Carina Campese ${ }^{a *}$, Talita Naiara Rossi da Silva ${ }^{b}$, Larissa Lunardon Gomes da Silva, \\ Julia Pierre Figueiredo ${ }^{c}$, Nilton Luiz Menegon ${ }^{c}$ \\ aUniversidade de São Paulo, São Carlos, SP, Brasil \\ bUniversidade Federal de Minas Gerais, Belo Horizonte, MG, Brasil \\ 'Universidade Federal de São Carlos, São Carlos, SP, Brasil \\ *carinacampese@yahoo.de
}

\begin{abstract}
There has been significant growth in air transport worldwide, as well as in Brazil. However, studies have emphasized that disabled, obese, and elderly passengers face difficulties when using this means of transport. Among these difficulties, issues related to passengers' own assistive devices, including damage, loss, or the impossibility of using during the entire flight, stand out. Therefore, the present study aims to understand the trends in assistive technology focusing on cabin design. This research is based upon literature review, interviews with manufacturers and research centers, visits to specialized trade fairs, and patent search. The results revealed a great diversity of assistive products, its trends, and an increase in their use, which affect aircraft cabin design, especially in terms of space, access, and stowage of these devices.
\end{abstract}

\section{Keywords}

Passengers with disabilities. Elderly passengers. Assistive technology. Air transport. Aircraft cabin.

\section{Introduction}

This study is part of the project entitled "Universal Cabin”, which was carried out through a partnership between Federal University of São Carlos and Embraer SA, between 2012 and 2014. The objective of this project was to identify the demands of disabled, obese, and elderly passengers in order to find solutions for aircraft cabins that meet the demands of this specific public.

The initial justifications of the project were air passenger transport sector discussions and changes in regulatory norms that could affect cabin design. In the Brazilian context, in 2012, the National Civil Aviation Agency of Brazil (ANAC) started to review the resolution No. 009 of 2007, current resolution No. 280 of 2013, which addresses the transport of passengers with special needs, among which are elderly passengers and passengers with disabilities (Agência Nacional de Aviação Civil, 2013b).
Therefore, understanding the demands of specific groups of passengers and be familiar with the technologies used by them is essential to come up with cabin design solutions that are more appropriate for the needs of potential groups of passengers, especially since there are no studies on this specific type of passengers in the Brazilian air transport.

Studies conducted in the country have addressed other aspects of passengers in the air transport such as seats and in-flight entertainment and cabin comfort, for example, studies carried out by Greghi et al. (2012, 2013) and Souza et al. (2013).

It is worth mentioning that studies addressing flying experiences have become more relevant since passenger comfort is seen as an important aspect of cab design due to competitiveness (Dumur et al., 2004; Quehl, 2001). 
Accordingly, Zhang et al. (1996) stated that passenger comfort and discomfort should be considered as two separate experience categories with different determinants. Furthermore, according to Greghi et al. (2013), the activity, more specifically the possibility/impossibility to perform an action, is in an intermediate element between comfort and discomfort, which is able to interfere with this relationship.

It is noteworthy that the activity is also considered central in the functionality and disability model proposed by the World Health Survey (2001), which establishes that the restriction or participation in society are determined by the interaction of environmental and personal factors, which, according to Guérin et al. (2001), are integrated by the activity.

According to the International Air Transport Association (2013) the air transport provides connectivity between different regions within a country and between different countries in the world. This means of transport is a key element of global growth. This sector experienced major growth in 2012, particularly in the emerging markets and passenger traffic.

Studies conducted by the National Civil Aviation Agency of Brazil (ANAC) show an increase of 188\% in demand for domestic and international air transport between 2003 and 2012. Between the years of 2011 and 2012, the increase in demand for domestic air transport was approximately 11\% (Agência Nacional de Aviação Civil, 2013a).

Despite the considerable growth of air transport passenger services, according to Poria et al. (2010), there are few studies on the experiences of people with disabilities when using this mode of transport in literature. The authors consider it to be surprising given the estimated size of this population and its economic power. In addition, their study highlights the aging of baby boomers, which indicates a tendency for elderly population growth and increase in the number of people with disabilities, as reported by the World Health Organization (World Health Survey, 2011).

According to the World Health Survey (2011), about 15\% of the adult population aged 18 years or older have some kind of disability. In Brazil, according to the 2010 Census, it is estimated that this population represents approximately 24\% of Brazilians (Brasil, 2013).

Studies carried out by Poria et al. (2010), Darcy (2012), Chang \& Chen (2012) and Yau et al. (2004) emphasized that the difficulties and needs of people with disabilities are evident at all stages of the journey. Among the key findings of their studies, an important aspect mentioned is about passengers' personal assistive devices.
Accordingly, Yau et al. (2004) pointed out that, while many passengers have the misfortune of having their baggage lost or mishandled, disabled passengers experience the anguish of losing a wheelchair. The study participants stated that they may find their wheelchair broken or with missing parts, for instance, its batteries (motorized wheelchairs), when they reach their destination.

Darcy (2012) also reported the loss and damage in personal devices. The author strongly emphasizes the restriction on the use of assistive devices and service animals on board the aircraft and the lack of on-board wheelchairs in some aircrafts, which can affect access to the lavatory, and the impossibility to use their own wheelchair during boarding, which implicates the need for several transfers during the journey.

This aspect was also reported by the participants in the study conducted by Freeman \& Selmi (2009) and Poria et al. (2010), who also pointed out difficulties that may arise when passengers are permitted to use their own wheelchair on board but they do not fit down the aisle of the aircraft and the passengers have to transfer to the on-board wheelchair, which was considered as uncomfortable.

It is important to mention that although there are studies on air transport for disabled and elderly passengers in the literature, there are no studies on this specific topic in Brazil and even though there are studies which identify difficulties associated with assistive technology in air transport, no studies on the devices used by passengers and their implications, especially for aircraft design, were found.

On the other hand, the reviewed studies that are related specifically to assistive technology address discussions regarding conceptualization and grounding in this field. In addition, this field involves products, services, methodologies, and several different practices to improve autonomy, independence, mobility, and participation. However, these studies are focused on products, especially those designed for the elderly and people with disabilities, and they do not necessarily correlate them with possible use in air transport.

Therefore, the purpose of the present study is to understand the trends related to assistive technology to substantiate and support future discussions about aircraft cabin design.

\section{2. "Assistive technology"}

The term assistive technology is used to designate a variety of products, features, services, apparatus, devices, strategies, and systems aimed basically at enhancing the remaining abilities and extending the functional capacity of individuals who have physical 
or cognitive difficulties, impairments, and disabilities that cause activity limitation and restrictions for social participation (Mello, 1997; Cook \& Hussey, 1995).

The field of assistive technology is under development in Brazil, and therefore the concept of assistive technology is still under debate. However, the Technical Assistance Committee has proposed a definition which is accepted nationwide:

[...] an area of knowledge, of interdisciplinary character, which includes products, resources, methodologies, strategies, practices, and services that aim to promote the functionality related to the activity and participation of people with disabilities, incapacities or reduced mobility seeking autonomy, independence, quality of life and social inclusion [...] (Brasil, 2007, p. 3).

Assistive technology products can be used in different situations in different purposes such as: adaptations to assist daily activities; communication systems; to enable the use of electronic devices; environmental control; structural adaptations in domestic professional, public or private environments; postural support; reduction or correction of visual or hearing impairments; adaptation of vehicles; and mobility solutions in general (Rocha \& Castiglioni, 2005).

The use of assistive technology provides people who have some type of disabilities with independence and autonomy (Galvão Filho, 2009), in addition to promoting welfare and social inclusion (Bersch, 2008).

The idea of independence and accessibility to products that are usable by all people is shared by the concept of universal design. According to Carletto \& Cambiaghi (2008), universal design proposes that technology should not be geared toward a specific group of people, but rather toward all people, and its goal is the reach, manipulation, and use of any environment or product by anyone, regardless of their anthropometric characteristics, posture, or mobility.

Its ultimate purpose is to avoid the creation of environments and special products for people with disabilities, enabling everyone to use the various spaces and objects safely and effectively (Carletto \& Cambiaghi, 2008).

In order to provide guidance in the design of products and environment, seven principles of universal design were established (Connell et al., 1997):

1. Equitable use: the design should be useful and marketable to people with diverse abilities;

2. Flexibility in use: the design should accommodate a wide range of preferences and abilities so that the same object can be used by all users;
3. Simple and intuitive: the use of the product should be easy to understand, regardless of the user's experience, knowledge, language skills, or concentration level;

4. Perceptible information: the product should communicate the necessary information effectively to the user, regardless of ambient conditions;

5. Tolerance for error (safety): the universal product should minimize hazards and the adverse consequences of accidental or unintended actions;

6. Low physical effort: the product should be used efficiently, comfortably, and with the least effort possible;

7. Size and space for approach and use: the universal product should provide space and size appropriate for approach, reach, manipulation, and use, regardless of the user's anthropometric characteristics, posture, or mobility.

When it comes to assistive technology and people with disabilities, the design of products and environments based on the universal design theory is a challenge since the need for specific techniques and equipment to use products and public spaces is still common (lmrie, 2012).

The popularization of universal design is timely and tends to be a progressive movement, reducing inequities of access that disabled people have to deal with on a daily basis (Imrie \& Hall, 2001). Taking into account the diversity of users of air transport, the universal design perspective can contribute to meet the needs of users.

\section{Accessibility standards}

Some accessibility standards and guidelines have been established to ensure safe and appropriate access for people with disabilities in various environments. The ABNT NBR 14273:1999, a technical standard established by the Brazilian National Standards Organization (ABNT), for example, specifically refers to airports and aircraft cabin space: it is mandatory that aircrafts with more than 100 seats have at least one on-board folding wheelchair, especially designed to fit down the aisle and the lavatory when unfolded (Associação Brasileira de Normas Técnicas, 1999).

The resolution number 280:2013 passed by ANAC (Agência Nacional de Aviação Civil, 2013b) - agency that addresses procedures related to the accessibility and carriage of passengers with special needs, concerns, among other issues, those related to technical assistance, seating, and on-board wheelchairs.

It is worth mentioning that among the passengers with special needs, the Resolution number 280:2013 
includes disabled people, people aged 60 years or more, pregnant and nursing mothers, people with children, people with reduced mobility, or anyone who has a specific condition that limits his/her autonomy as a passenger (Agência Nacional de Aviação Civil, 2013b). However, the present study focuses only on disabled, elderly, and obese passengers.

With regard to technical assistance, passengers can use their personal mobility aid devices to get to the boarding gate, provided they follow all airport security procedures. These devices can be stowed in designated priority storage areas in the cabin or in the overhead storage compartment when considered as priority or fragile items, and they should be made available to the passenger shortly after deplaning. This resolution also addresses measures to be taken in case of loss or damage of these devices (Agência Nacional de Aviação Civil, 2013b).

With regard to the seats, this resolution establishes that special seats with removable or folding armrests should be provided near the aisle located in the front and rear of the aircraft, closest to the entrance/exit doors. Aircrafts with 30 or more seats must have at least one half of the armrests on aisle seats removable, and aircrafts with 100 or more seats must have on-board wheelchairs.

The ABNT NBR 9050:2004 (Associação Brasileira de Normas Técnicas, 2004) establishes technical standards and guidelines for the design, construction and adaptation of buildings, furniture, equipment, and spaces. Although this standard does not specifically address issues related to transportation vehicles, it could be used as a reference in situations that involve space measurement, for example. Accordingly, this standard establishes the minimum aisle width dimensions $(0.9 \mathrm{~m}$ for the aisle length of $4 \mathrm{~m}$ ) and the minimum overall space dimension $(0.8 \times 1.2 \mathrm{~m})$ to allow full wheelchair accessibility. The seats designated for obese people should be twice as large as the standard sized aircraft seat and have a minimum of $0.6 \mathrm{~m}$ of space for the passenger's legs.

\section{Materials and methods}

A literature review on assistive technology was conducted between October and December 2012 and was updated between May and August 2013. The databases ScienceDirect, Scopus and CAPES (Coordination for the Improvement of Higher Education Personnel, a Brazilian foundation) open access journals were searched using the following keywords: assistive technology, air transport, cabin, emerging technologies, trends. It is worth mentioning that searches combining the term assistive technology with the others were also conducted. A total of 15 studies were reviewed, including mainly those that have been published from 2009.

Data collection was carried out through interviews with research centers and companies that produce or provide assistive technology products and services. In addition, visits to trade fairs of Rehabilitation and Assistive Technology were made and a patent search was performed.

The companies selected for visits included some of the leading manufacturers of assistive technology products and services in the country and are located in the cities of São Paulo and Campinas (SP). The open-ended interview questions mainly addressed the characteristics of the company, products manufactured, and trends in the field of assistive technology. Were visited three companies, identified as E1, E2 and E3 and, one resource guide for assistive technology, identified as E4, which is supported by the Federal Government (E4). The characteristics of the places where the interviews were conducted are shown in the Table 1.

Table 1. Characteristics of the places visited.

\section{ID}

\begin{tabular}{|c|c|}
\hline E1 & $\begin{array}{l}\text { A 44-year old company located in the Sao Paulo city. It was engaged in transport of people with disabilities for } 22 \text { years. } \\
\text { Today, the company manufactures products related to accessibility for people with disabilities, focusing mainly on transport } \\
\text { and general adaptations to vehicles based on customer needs researches. This company also sells domestic and imported } \\
\text { assistive technology products. }\end{array}$ \\
\hline E2 & $\begin{array}{l}\text { A multinational company, founded in Germany, operating in over } 40 \text { countries. In Brazil, its headquarters is located in } \\
\text { Campinas. It manufactures innovative and rehabilitation products for people with physical disabilities, especially prosthesis, } \\
\text { wheelchairs, and orthoses. }\end{array}$ \\
\hline E3 & $\begin{array}{l}\text { A company located in the city of Guarulhos engaged in the development and production of pedagogical and inclusive games } \\
\text { and the sale of domestic and imported products related to accessibility for people with disabilities, such as computer mouse } \\
\text { and keyboards, Braille menus, grab bars, canes, and adapted wheelchairs. In addition, it provides consultancy services on } \\
\text { accessibility. }\end{array}$ \\
\hline E4 & $\begin{array}{l}\text { It was stablished in } 2012 \text { to assist the implementation of the program "Living Without limits". It is a government funded } \\
\text { resource guide for assistive technology that manages the supply and demands of this field in the country. It provides } \\
\text { consultancy and technical support services for the ministries in the assistive technology area. }\end{array}$ \\
\hline
\end{tabular}


The following trade fairs were visited: International Fair for Rehabilitation, Inclusion, Accessibility, and Adapted Sports (REATECH); Rehabilitation Fair+Forum; and Hospital Fair, which were all held in São Paulo in 2013. The data were collected using product information cards containing the name of the product, its manufacturer, the forecast for market release, and specific product features.

The patent search was performed by accessing databases of the National Institute of Industrial Property (INPI), the World Intellectual Property Organization (WIPO), the European Patent Office (EPO), and the United States Patent and Trademark Office (USPTO) using the following keywords: assistive technology and disability. Furthermore, patents were also searched using the name of some assistive technology manufacturers identified in this study.

It is important to highlight that the patent search was performed considering patents issued after 2007 and activities carried out within the context of air transport. They were organized according to the Classification of Assistive Technology Products (International Organization for Standardization, 2011).

The Centers for Research on Assistive Technology visited were sent email messages. Firstly, a total of 29 research centers (2013) were sent an email by the National Reference Center for Assistive Technology (CNRTA), including a letter describing the study and a questionnaire. Only one research center returned the survey. Later, two other research centers were contacted directly and visited. The same questionnaire sent by email was used during the visits; it contained questions about the research center characteristics, projects and programs, and trends in the field of assistive technology.

Research centers visited are identified as N1 and N2. They belong to Federal Universities located in the state of São Paulo. The research center N3, which returned the survey by email, belongs to a Federal Institute located in the state of Rio Grande do Sul. These centers carry out research on a variety of topics such as demand mapping, motion analysis to investigate "wheelchair" propulsion, development of motorized wheelchairs and wheelchairs with stair climbing ability, rehabilitation devices, robotic prosthesis, and virtual accessibility resources.

Interviews with manufacturers and suppliers of assistive technology products and services were recorded, and they subsequently were transcribed organizing the information gathered according to the issues addressed. Visits to the research centers were not recorded, but the same interview questions were applied as a questionnaire by interviewers, and the data were sent back to the research centers for validation. The patents were organized in "tables" including identification, a description, and figures (if available). A descriptive data analysis was performed to identify the trends found in this study.

\section{Results}

It is important to mention that based on the purpose of this study, data collection was focused on the search for products and devices although assistive technology also includes services, methodologies, and practices.

\subsection{Products and patents}

A wide range of products designed for people with physical disabilities and products that aim to enhance access to information and electronic devices were identified especially in specialized trade fairs.

There are products for personal mobility that are under development or have just been launched in the market. The manual wheelchairs with new shock absorbers are one example of this. They are made of different materials (polyamide, carbon fiber, aluminum), which reduce the frame weight and enable the use of the same wheelchair for different purposes, for example, it can serve as a bathroom chair, a transport chair, or a chair for security screening (X-ray at airports).

In addition, there is a wide range of motorized wheelchairs, stair climbing wheelchairs, and scooters. These devices incorporate technologies that enable their use by people with severe disabilities, especially those with upper-limb motor impairment; however, they are heavy, making their transport more difficult.

Robotic exoskeletons for people with physical disabilities were also found in the literature (Cowan et al., 2012) and product research, for example, the bionic exoskeleton of Ekso Bionics US (Ekso, 2013). Exoskeletons are an external structural mechanism with joints and links matching those of the human body and that play the role of human limbs.

As for products to improve the environment and access to transport, a concern with boarding and debarking vehicles was observed. Therefore, the products found are related to ramps, wheelchair lifts for buses, wider seats for obese people, on-board wheelchairs that can be combined to a standard seat eliminating physical transfers to other wheelchairs within the aircraft, and design of accessible aircraft lavatories for obese passengers and passengers with disabilities or their personal aids.

Products designed to provide mobility and guidance for visually impaired people, such as a guide with 
audio information signs and tactile features and a device that delivers vibrational signals, were identified.

Products that provide accessibility to information and communication were also identified, for example, portable electronic magnifiers; smartphones with audio-tactile features; a bionic eye that transmits visual information to sensory areas in the brain; and other devices such as glasses, camera, and headphones that convert environmental information into audio information.

For people with hearing impairment, there has been an recent development of hearing aid "devices" providing wireless connection to cell phones, landline phones, and TVs. Resources to facilitate the use of electronic devices were also identified, for example, a smartphone app that improves communication through text messages and images and a cell phone feature with flashing light to indicate that a text message was received.

Other products identified are related to personal care and protection, adapted vehicles, orthosis and prosthesis, and products for a constructed environment and wheelchair adaptations, such as a system that adapts the wheelchair, making it a "handbike".

With regard to the patents found, most are related to personal mobility and transport, accessibility in constructed environments, and communication, information, and access to electronic devices.

Among the patents of mobility products for people with physical disabilities, wheelchairs with the ability of overcoming obstacles and climbing steps stand out, for example, the patents "Device enabling an electric wheelchair to cross obstacles" (Ohruh, 2011) and "the star-shaped wheelchair" (Moraya, 2012). Moreover, patents of systems for motorization of manual wheelchairs, a seat attached to crutches, brakes and armrests were also found. As for products designed for people with visual impairment, patents of canes with sensors that vibrate to alert users to approaching objects, such as the electronic cane (Ramirez, 2007), were identified.

With regard to mobility devices, patents found are related to solutions for accommodation and access to vehicles. For example, lifting platforms and elevators for boarding and deplaning aircrafts or for use in buses, such as those presented in the patents "Ladder with vertical elevator for access to aircrafts" (Hummel, 2012), an elevator for boarding and debarking vehicles (Busscar Ônibus, 2010), moving the belt platform for boarding and debarking buses (Ramos, 2009) and the moving platform with an electric traction system to assist disabled people (Pellenz, 2011).
A special seat that combines a standard aircraft seat with a wheelchair, the patent entitled "Mobile aircraft seat-wheelchair for disabled passengers and people requiring assistance" (Soldatos, 2009), was developed to enable passengers with disabilities to use the same chair from their arrival at the departure airport to the destination airport, therefore remaining in the chair during the flight since it is locked on the aircraft cabin floor.

With regard to access to information and communication, patents related to access to electronic devices (either for information input or output) stand out. Similarly, alternative solutions for mouse and keyboard use were found, for example, the patent of a device for people with physical disabilities who have difficulty using a conventional mouse (Sousa, 2011) and the patents entitled "Tongue operated magnetic sensor based wireless assistive technology" (Ghonvanloo \& Krischnamurthy, 2011) and "Multimodal communication system" (Ghonvanloo \& Huo, 2013), which use tongue motion, "head" motion, forehead and eyebrows muscle motion, voice commands, and a keyboard that produces groups of characters.

Moreover, among the patents found, there are resources to support the understanding of information output, such as converters of audio texts, images, and Braille, for example, as described in the patent "Assistive device for converting an audio signal into a visual representation" (Clarke \& Rix, 2013).

The products and patents found indicate mainly a tendency in the development of resources for people with severe cognitive and motor impairment, motorized wheelchairs with alternative controls, solutions for electronic device use, and access to information and communication.

\subsection{Trends in "assistive technology"}

Table 2 shows the trends in the assistive technology field according to the perspective of the interviewed companies, resource guide for assistive technology, and research centers.

According to the results presented in Table 2 and to products and patents found, some trends in the assistive technology area were identified:

1. Development of lightweight wheelchairs that are easier to maneuver, as highlighted in $\mathrm{N} 1$ and $\mathrm{N} 2$, motorized chairs with distinctive features and "smart" wheels for autonomous navigation, and wheelchairs with robotic features, as shown in E1, $\mathrm{N} 1$, and $\mathrm{N} 2$;

11. Development of products for people with severe disabilities, especially systems for environmental control, mobility devices, resources to assist with access to electronic devices, information, and 
Table 2. Trends in assistive technology.

\begin{tabular}{|c|c|}
\hline ID & Tendencies found \\
\hline E1 & - Improvement in terms of mobility and transport for disabled people including personal mobility or mobility devices. \\
\hline E2 & $\begin{array}{l}\text { - Assistive technology electronic products; } \\
\text { - Wheelchairs that incorporate user needs, for example, a wheelchair with phones or television remote controls. }\end{array}$ \\
\hline E3 & $\begin{array}{l}\text { - The reduced cost of assistive technology products; } \\
\text { - Expansion of sale channels (a network and local sales) of assistive technology products; } \\
\text { - Increased participation of people with disabilities in society }\end{array}$ \\
\hline E4 & - Changes in the school building structure and school supplies for people with disabilities. \\
\hline N1 & $\begin{array}{l}\text { - Smart wheelchairs with voice commands and autonomous navigation; } \\
\text { - Wheelchairs with robotic features, for example, a chair with mounted robotic arms that assist people with picking up objects; } \\
\text { - Development of good quality low cost wheelchairs and accessories; } \\
\text { - Development of very lightweight wheelchairs; } \\
\text { - Provision of assistive technology resources through the Unified Health } \\
\text { - System (SUS), Brazilian publicly funded health care system. }\end{array}$ \\
\hline N2 & $\begin{array}{l}\text { - Motorized wheelchairs with improved accessibility; } \\
\text { - Development of lighter batteries for motorized wheelchairs; } \\
\text { - Development of alternative motorized wheelchairs control approaches using a voice command. } \\
\text { - Development of autonomous navigation wheelchairs. }\end{array}$ \\
\hline N3 & - Low cost assistive technology products. \\
\hline
\end{tabular}

communication. The greater use of electronics in assistive technology devices, as highlighted in E2, N1, and N2, can also be observed by the wide variety of devices, such as motorized wheelchairs, stair climbing wheelchairs, scooters, and electronic canes, which were found among the products and patents in the searches performed (Ramirez, 2007);

111. Multifunctional products, following the trend towards media convergence identified in the electronics market. For example, a tablet coupled to a motorized wheelchair enables users to control the chair and home lighting and appliances (phone, and television), or a wheelchair that can travel on a flat ground and climb up and down stairs, as also described in the patents "Device enabling an electric wheelchair to cross obstacles" (Ohruh, 2011) and "The star-shaped wheelchair" (Moraya, 2012);

IV. Development of technologies for caring out various activities, driven by the increasing presence and participation of people with disability and elderly in society, including travel and air travel transport scenarios. Some examples of these technologies are devices to provide access to means of transport, wheelchairs to transport people from the airport to the aircraft cabin, as described in the patent "Mobile aircraft seat-wheelchair for disabled passengers and people requiring assistance" (Soldatos, 2009). A major concern regarding the use of these devices in different situations was also evidenced. For example, in the development of wheelchairs made from special materials, so that they can be used both in the tub or shower and as a transport chair and that can fit through a security screening archway (X- Ray).

\section{Discussion}

Based on the findings of this study, it can be observed that the development of assistive technology will bring benefits to different users of air transport services. With regard to the development of wheelchairs, mainly motorized chairs, according to trends 1 and 11, an increase in their weight and the need for more careful storage of the chair and batteries were observed. Therefore, they require a suitable storage area for transport in the cabin or in the baggage compartment. This also includes the storage of manual chairs since, after all, there are a number of reports of damage of assistive devices. Another important aspect is the thorough and essential training of air transport employees to handle these devices.

Moreover, as stated in trends 1,11 , and IV, in order for people using wheelchairs or other mobility devices on boarding and deplaning the aircraft with independence and safety, according to the regulations of this sector, there is a need for wider aisles and more space to access the cabin (space in the galley area) and the seat after boarding using ambulift through the service door to enable them to arrive at their seat using their own wheelchair or crutches, for example, and to transfer into their seat. Therefore, the wheelchair dimensions established by ABNT 9050:2004 could be considered. It is worth mentioning, however, that there is a tendency towards the increase in the number of motorized wheelchairs and scooters, tendency 11, devices that have larger overall dimensions (Associação Brasileira de Normas Técnicas, 2004).

Another perspective is related to the design of seats combined with on-board wheelchairs that have been developed to reduce the need for multiple 
transfers during the flight since the same seat would be used to move the passenger through the airport and within the aircraft, according to trends 111 and IV, highlighting multifunctional technologies for use in different activities or moments.

Nevertheless, it is important to remember that personal assistive devices are especially adapted to meet the needs of users and ensure their independence, which can be limited if they are not brought onboard. The use of these seats will also have implications in terms of locking them on the cabin floor and in terms of the space required for wheelchair mobility at the entrance and in the aisles of the aircraft. Furthermore, the independence of the passenger to maneuver the device is not preserved in the designs identified.

New developments related to access to information and communication suggest solutions that could be considered in the development of in-flight entertainment systems, enabling their use by people with sensory impairments or even facilitating their control by people with severe motor disabilities.

The data presented indicate that the advances in the field of assistive technology will influence aircraft cabin design due to the need to reevaluate spaces and access, in order to enable passengers to keep their personal assistive device at least until boarding and seating and after deplaning, or due to the developments in this field that may bring solutions and ideas for the incorporation of new features in the cabin design to improve access to information and in-flight entertainment.

As for the circulation spaces, it is worth noting that the ABNT NBR 14273:1999 and the Resolution number 280:2013 by ANAC have established the mandatory requirement for on-board wheelchairs on some aircrafts with dimensions consistent with the cabin aisle space, but they have not established the minimum required dimensions for aisle space. In other environments, "buildings" for example, there are minimum requirements, established ABNT NBR 9050:2004, for heavy traffic areas, such as hallways and bathrooms among others. Despite the difficulty of the direct application of this requirement in an aircraft cabin, normative requirements based on this norm, focusing on accessibility within the cabin, would be a significant advance.

Another issue to be improved is the storage and transport of assistive devices to avoid the damage reported. It would be better for passengers to have their devices stored in the cabin rather than in the baggage compartment. Therefore, specific storage areas for assistive devices need to be reevaluated since not even crutches fit in some overhead compartments, much less a wheelchair. Moreover, it is recommended that the cabin stowage area should allow passengers access to the device during the flight.

\section{Conclusions}

Based on the findings of this study, it can be concluded that there is a wide variety of products and assistive technology devices and a tendency towards further developments incorporating electronic and robotic resources. This improve the ability of people who need these resources promoting their independence and participation in social contexts.

In Brazil, there is a tendency towards greater dissemination of assistive technology (especially due to government support for research and national production), product cost reduction, and eligibility for acquisition and distribution of these products through the Brazilian Unified Health System (SUS).

Therefore, it is believed that along with the higher travel propensity of the disabled and older people, the use of different devices for travel will greatly increase, suggesting that there are issues that require further discussion and consideration by the aircraft industry, mainly to guarantee the use of personal assistive devices during all phases of the flight (gate-to-gate).

This study addressed issues related to assistive technology devices and trends in this field that may impact on the passenger cabin design of transport aircraft. Further studies need to be carried out to understand the technical specifications of existing and new devices and to thoroughly investigate how to effectively implement the changes that have already been made considering economic aspects and other norms and resolutions of this sector.

Furthermore, two other studies are being carried out to understand the perspectives of passengers and flight attendants on the needs of users in terms of accessibility to air transport seeking to use information and views expressed by different actors to support future advances and the design of new devices.

Studies on the nature of work carried out by those who operate accessibility equipment in airports and provide assistance for passengers on the ground are also necessary to improve the entire travel experience and ensure it is smooth and efficient meeting the needs of passengers with disabilities or reduced mobility and elderly passengers. 


\section{References}

Agência Nacional de Aviação Civil - ANAC. (2013a). Anuário do transporte aéreo: dados estatísticos e econômicos de 2012. Brasília. Retrieved in 13 August 2014, from http:// www2.anac.gov.br/estatistica/anuarios.asp

Agência Nacional de Aviação Civil - ANAC. (2013b, July 16). Resolução $n^{\circ} 280$, de 11 de Julho de 2013. Dispõe sobre os procedimentos relativos à acessibilidade de passageiros com necessidade de assistência especial ao transporte aéreo e dá outras providências. Diário Oficial da União. Retrieved in 13 August 2014, from http://www2.anac.gov. br/biblioteca/resolucao/2013/RA2013-0280.pdf

Associação Brasileira de Normas Técnicas - ABNT. (1999). NBR 14273: acessibilidade da pessoa portadora de deficiência no transporte aéreo comercial. Rio de Janeiro. 5 p. Retrieved in 13 August 2014, from http://www.pessoacomdeficiencia. gov.br/app/sites/default/files/arquivos/\%5Bfield_generico_ imagens-filefield-description\%5D_12.pdf

Associação Brasileira de Normas Técnicas - ABNT. (2004). NBR 9050: acessibilidade a edificações, mobiliário, espaços e equipamentos urbanos. Rio de Janeiro. 97 p. Retrieved in 13 August 2014, from http://www.pessoacomdeficiencia. gov.br/app/sites/default/files/arquivos/\%5Bfield_generico_ imagens-filefield-description\%5D_24.pdf

Bersch, R. (2008). Introdução à tecnologia assistiva. Porto Alegre: Centro Especializado em Desenvolvimento Infantil.

Brasil, Presidência da República, Secretaria Nacional dos Direitos Humanos, Comitê de Ajudas Técnicas. (2007). Ata da Reunião VII, de dezembro de 2007. Brasília. Retrieved in 13 August 2014, from http://portal.mj.gov.br/corde/ arquivos/doc/Ata_Vll_Reuni\%C3\%A30_do_Comite_de_ Ajudas_T\%C3\%A9cnicas.doc

Brasil, Blog do Planalto. (2013). Tecnologia assistiva terá rede nacional de pesquisa e desenvolvimento. Brasília. Retrieved in 13 August 2014, from http://blog.planalto.gov.br/ projetos-de-tecnologia-assistiva-apresentam-avancossignificativos-avalia-secretario-para-inclusao-social/

Busscar Ônibus. (2010). Elevador para embarque e desembarque de passageiros em veículos. MU 8900057-9 U2. Brazil. Retrieved in 13 August 2014, from http://www.patentesonline.com. br/elevador-para-embarque-e-desembarque-de-passageirosem-ve-culos-238673.html

Carletto, A. C., \& Cambiaghi, S. (2008). Desenho Universal: um conceito para todos. São Paulo: Instituto Mara Gabrilli.

Chang, Y., \& Chen, C. (2012). Meeting the needs of disabled air passengers: factors that facilitate help from airline and airports. Tourism Management, 33(3), 529-536. http:// dx.doi.org/10.1016/j.tourman.2011.06.002.

Clarke, R., \& Rix, A. W. (2013). Assistive device for converting an audio signal into a visual representation. WO 2013050749 A1. United Kingdom. Retrieved in 13 August 2014, from http://www.google.com/patents/W02013050749A1?cl=en

Connell, B. R., Jones, M., Mace, R., Mueller, J., Mullick, A., Ostroff, E., Sanford, J., Steinfeld, E., Story, M., \& Vanderheiden, G. (1997). The principles of universal design. Raleigh: Center of Universal Design, North Carolina State University.

Cook, A. M., \& Hussey, S. M. (1995). Assistive technologies: principles and practices. St. Louis: Mosby.

Cowan, R. E., Fregly, B. J., Boninger, M. L., Chan, L., Rodgers, M. M., \& Reinkensmeyer, D. J. (2012). Recent trends in assistive technology for mobility. Journal of Neuroengineering and Rehabilitation, 9(1), 1-8. PMid:22520500.
Darcy, S. (2012). (Dis) Emboied air travel experiences: disability, discrimination and the effect of a discontinuous air travel chain. Journal of Hospitality and Tourism Management, 19(1), 1-11. http://dx.doi.org/10.1017/jht.2012.9.

Dumur, E., Barnard, Y., \& Boy, G. (2004). Designing for comfort. In D. Waard, K. A. Brokhuis \& C. M. Weikert (Eds.), Human factors in design (pp. 111-127). Maastricht: Shaker Publishing.

Ekso. (2013). Ekso bionics. Richmond. Retrieved in 27 July 2012, from www.eksobionics.com/ekso

Freeman, 1., \& Selmi, N. (2009). French versus Canadian tourism: response to the disabled. Journal of Travel Research, 49(4), 471-485. http://dx.doi.org/10.1177/0047287509349268.

Galvão Filho, T. A. (2009). A Tecnologia Assistiva: de que se trata? In G. J. C. Machado \& M. N. Sobral (Eds.), Conexões: educação, comunicação, inclusão e interculturalidade (1st ed., pp. 207-235). Porto Alegre: Redes.

Ghonvanloo, M., \& Huo, X. (2013). Multimodal communication system. US 20130090931 A1. Washington. Retrieved in 13 August 2014, from http://www.google.com/patents/ US20130090931

Ghonvanloo, M., \& Krischnamurthy, G. (2011). Tongue operated magnetic sensor based wireless assistive technology. US 8044766 B2. Washington. Retrieved in 13 August 2014, from https://www.google.com/patents/US8044766

Greghi, F. M., Rossi, T. N., Souza, B. G., \& Menegon, N. L. (2012). Contributions from the activity analysis to the products development project: case study based on a project of innovation and comfort in aircraft's cabins. Work, 41(Suppl 1), 55-60. PMid:22316700.

Greghi, M. F., Rossi, T. N., Souza, J. B., \& Menegon, N. L. (2013). Brazilian passengers' perceptions of air travel: Evidences from a survey. Journal of Air Transport Management, 31, 27-31. http://dx.doi.org/10.1016/j.jairtraman.2012.11.008.

Guérin, F., Laville, A., Daniellou, F., Duraffourg, J., \& Kerguelen, A. (2001). Compreender o trabalho para transformá-lo: a prática da ergonomia. São Paulo: Edgard Blücher. 200 p.

Hummel, R. (2012). Ladder with vertical elevator for access to aircrafts. US 2012205194 A1. Washington. Retrieved in 13 August 2014, from http://www.google.com/patents/ US20120205194</patent>.

Imrie, R. (2012). Universalism, universal design and equitable access to the built environment. Disability and Rehabilitation, 34(10), 873-882. http://dx.doi.org/10.3109/09638288.20 11.624250. PMid:22054109.

Imrie, R., \& Hall, P. (2001). Inclusive design. London: Routledge. http://dx.doi.org/10.4324/9780203362501.

International Air Transport Association - IATA. (2013). Annual Review 2013. Montreal. Retrieved in 13 August 2014, from http://www.iata.org/about/Documents/iata-annualreview-2013-en.pdf

International Organization for Standardization - ISO. (2011). ISO 9999: produtos de apoyo para personas con discapacidad: clasificación y terminologia. Genebra. Retrieved in 15 February 2013, from www.unit.org.uy/misc/catalogo/ UNIT-1S09992011.pdf

Mello, M. (1997). Tecnologia assistiva. In J. M. D. Greve \& M. M. Amatuzzi (Eds.), Medicina de reabilitação aplicada à ortopedia e traumatologia. São Paulo: Manole.

Moraya, L. A. (2012). Cadeira de rodas em estrela. MU 9000964-9U2. Brazil. Retrieved in 13 August 2014, from 
http://www.patentesonline.com.br/cadeira-de-rodas-emestrela-290815.html

Ohruh, M. (2011). Device enabling an electric wheelchair to cross obstacles. WO 2011/095753. France. Retrieved in 13 August 2014, from http://patentscope.wipo.int/search/ en/W02011095753

Pellenz, J. A. (2011). Disposição construtiva em movimentador de plataformas de transporte veicular destinadas a portadores de deficiência e outros através de tração elétrica. MU 8902421-4 U2. Brazil. Retrieved in 13 August 2014, from http://www.patentesonline.com.br/disposi-o-construtivaem-movimentador-de-plataformas-de-transporte-veiculardestinadas-264130.html

Poria, Y., Reichel, A., \& Brandt, Y. (2010). The flight experiences of people with disabilities: an exploratory study. Journal of Travel Research, 49(2), 216-227. http://dx.doi. org/10.1177/0047287509336477.

Quehl, J. (2001). Comfort studies on aircraft interior sound and vibration (Doctor thesis). Universität Oldenburg, Oldenburg. Retrieved in 13 August 2014, from http:// oops.uni-oldenburg.de/340/2/quecom01.pdf

Ramirez, A. R. G. (2007). Bengala eletrônica. MU 8601042-5. Brazil. Retrieved in 13 August 2014, from http://www. patentesonline.com.br/bengala-eletr-nica-63384.html

Ramos, A. C. S. (2009). Plataforma rolante para o embarque e desembarque de pessoas com dificuldade de locomoção nos ônibus. Pl 0703215-3 A2. Brasília: Ministério do Desenvolvimento, Indústria e Comércio Exterior. Retrieved in 13 August 2014, from http://www.patentesonline.com. $\mathrm{br} /$ plataforma-rolante-para-o-embarque-e-desembarquede-pessoas-com-dificuldade-de-locomo-197808.html
Rocha, E. F. \& Castiglioni, M.C. (2005). Reflexões sobre recursos tecnológicos: ajudas técnicas, tecnologia assistiva, tecnologia de assistência e tecnologia de apoio. Revista Terapia Ocupacional da Universidade de São Paulo, 16(3), 97-104.

Soldatos, T. (2009). Mobile aircraft seat-wheelchair for disabled passengers and people requiring assistance. US 82009/0308672 A1. Washington. Retrieved in 13 August 2014, from http:// www.google.com/patents/US20090308672

Sousa, W. J. F. (2011). Dispositivo para pessoas com deficiência física que tem limitação no uso do mouse convencional. PI 1000671-0 A2. Brasília: Ministério do Desenvolvimento, Indústria e Comércio Exterior. Retrieved in 13 August 2014, from http://www.patentesonline.com.br/dispositivo-parapessoas-com-defici-ncia-f-sica-que-tem-limita-o-no-usodo-mouse-276520.html

Souza, J. B. G., Menegon, N. L., Sticca, M. G., \& Rossi, T. N. (2013). Parâmetros relacionados ao conforto e passageiros: uma pesquisa das práticas adotadas por fabricantes de poltronas. Produção, 23(1), 157-167.

World Health Survey - WHS. (2001). Classificação Internacional de Funcionalidade Incapacidade e Saúde (CIF). Geneva.

World Health Survey - WHS. (2011). Relatório mundial sobre a deficiência. São Paulo: Secretaria de Estado dos Direitos da Pessoa com Deficiência de São Paulo.

Yau, M. K. S., Mckercher, B., \& Packer, T. L. (2004). Traveling with a disability: more than an access issue. Annals of Tourism Research, 31(4), 946-960. http://dx.doi.org/10.1016/j. annals.2004.03.007.

Zhang, L., Helander, M. G., \& Drury, C. G. (1996). Identifying factors of comfort and discomfort in sitting. Human Factors, 38(3), 377-389. http://dx.doi.org/10.1518/001872096778701962. 